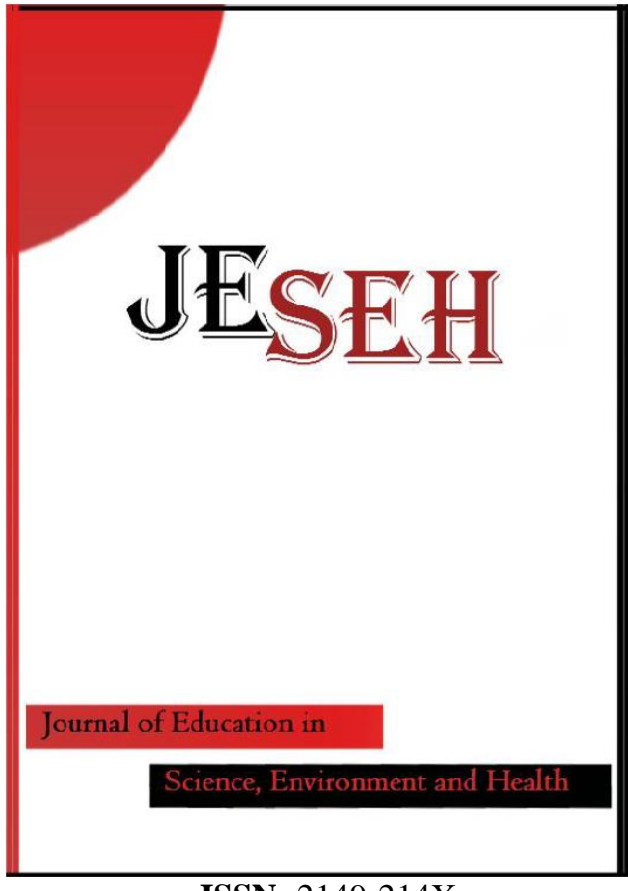

ISSN: $2149-214 \mathrm{X}$

\section{Journal of Education in Science, Environment and Health}

www.jeseh.net

A Thematic Review of Tablet-Based Science Education Studies

Ummuhan Ormanci, Salih Cepni

Uludag University

To cite this article:

Ormanci, U. \& Cepni, S. (2019). A thematic review of tablet-based science education studies. Journal of Education in Science, Environment and Health (JESEH), 5(1), 36-54. DOI:10.21891/jeseh.502498

This article may be used for research, teaching, and private study purposes.

Any substantial or systematic reproduction, redistribution, reselling, loan, sub-licensing, systematic supply, or distribution in any form to anyone is expressly forbidden.

Authors alone are responsible for the contents of their articles. The journal owns the copyright of the articles.

The publisher shall not be liable for any loss, actions, claims, proceedings, demand, or costs or damages whatsoever or howsoever caused arising directly or indirectly in connection with or arising out of the use of the research material. 


\title{
A Thematic Review of Tablet-Based Science Education Studies
}

\author{
Ummuhan Ormanci, Salih Cepni
}

\begin{tabular}{|c|c|}
\hline Article Info & Abstract \\
\hline Article History & The use of tablet in schools has been getting importance in a parallel with any \\
\hline $\begin{array}{l}\text { Received: } \\
08 \text { March } 2018\end{array}$ & $\begin{array}{l}\text { investigated on the variables such as success and attitude in the literature and the } \\
\text { number of studies increased related to the applications that can be used in tablets. }\end{array}$ \\
\hline $\begin{array}{l}\text { Accepted: } \\
19 \text { December } 2018\end{array}$ & $\begin{array}{l}\text { In this context, it was considered that analyzing the studies conducted in the field } \\
\text { of science education, which was one of the courses where tablet use was } \\
\text { recommended, will be important for both teacher - prospective teacher }\end{array}$ \\
\hline Keywords & $\begin{array}{l}\text { candidates who were practitioner and literature. The aim of this study was to } \\
\text { thematically examine and analyze tablet-based science education studies. } 25\end{array}$ \\
\hline Scienc & articles were exposed to this thematic review via the matrix developed by \\
\hline ary education & Ormanci et al. (2015). The matrix consists of two parts-general properties (type \\
\hline & of journals, years, etc.) and content (rationales, aims, research methods, etc.). \\
\hline Technology & The results indicated rationales of related studies were very limited. Further, \\
\hline Thematic review & $\begin{array}{l}\text { there were experimental studies examining the effects of tablet-based science } \\
\text { education on student success and performance. None of previous studies } \\
\text { examined the effects of tablet-based science education on the participants' skills, } \\
\text { which should be investigated in future studies. }\end{array}$ \\
\hline
\end{tabular}

\section{Introduction}

Technological advancements as well as changes in the education policies of countries in parallel to the advancements have led the countries to use various technological devices such as tablets or smart boards in their education programs. As stated by Inagaki et al. (2011), educational reforms carried out via information and communication technologies are the priorities of governments all over the world. It is known that computers have become a part of daily lives of both adults and children in many countries (Straker, Coleman, Skoss, Maslen, Burgess-Limerick and Pollock, 2008). The technological advancements which hold an important place among the recent developments in the world have affected all areas of life including education and teaching (Ilyasoglu and Aydin, 2015). It can be stated that tablets are among the devices that have recently gained importance along with technological advancements in addition to computers. As stated by Amirnudin and Sulaiman (2013), tablet technology has become one of the most rapidly advancing technologies in the world. The portability of the tablets as well as the ease of note taking have resulted in increased attention towards them in various sectors such as health, construction, government and education (El-Gayar, Moran and Hawkes, 2011). In this regard, tablets have gained rapid popularity and used as a strong tool of education in classrooms (Hocanın and Iscioglu, 2014). Cuhadar (2014) stated that tablet use has gained popularity at university level. In addition, it can be stated that the importance given to tablets has been increasing in all levels of education and that tablet use gained popularity. It can be propounded that the popularity of tablets are since the properties of tablets are quite suited to educational activities (Gill, 2007). Since tablets have different functions that enrich the educational environments, they make positive impacts on student learning (Varank, Yeni and Gecu, 2014).

Tablets are functional laptop computers which include a touch screen for data input (Romney, 2011). In other words, they are laptop computers including properties that enable direct input to the screen for creating electronic documents against to traditional computer applications allowing the use of pens via stylus with simulated paper properties (Enriquez, 2009; 2010). In this regard, tablets are becoming more practical in comparison with computers due to their mobility (portability) and digital properties (Gubacs-Collins and Juniu, 2009). Different than traditional laptop computers, tablets are equipped with a screen digitizer that enables users to write directly on the screen as well as a stylus pen (Cao, 2014; Galligan, Loch, McDonald and Taylor, 2010; Ozok, Benson, Chakraborty and Norcio, 2008; Reboli, 2007). In addition, tablets have additional functionalities that provide a digital link to the users for creating direct information on the screen (Moore, Utschig, Haas, Klein, Yoder, Zhang et al., 2008). The laptop computers generally have a keyboard and a mouse whereas the primary input device has been designed as a pen for tablets (Chambers, Chidanandan, DeVasher, Merkle, Minster, Mitra-Kirtley et al., 2006). As it can be understood, tablets are connection free functional mobile 
computers (Park and del Pobil, 2013). In this regard, tablets provide various additional choices such as mobility, direct interaction with the screen which make them more effective than computers and leading to their increased importance in classroom use.

There are mainly two different methods for the use of tablets in classrooms. They are interactive mode and noninteractive mode (Chen and Sager, 2011). Similarly, Sheehy, Kukulska-Hulme, Twining, Evans, Cook and Jelfs (2005) purposed in their studies that some students use tablets to access video, web links and worksheets whereas others use tablets as data projectors instead of smart boards. In this regard, it can be stated that many applications have been developed for interactive and non-interactive tablet use in teaching environments. Some of these applications can be used in all courses whereas others are directly field related applications. As affirmed by Tran, Ma, Sharma and Liu (2006), the current Tablet PC tools provided by Microsoft are Input Panel, Office OneNote, Windows Journal, StickyNotes and EducationPack in addition to Timesheet Tools such as Business Calendar, Financial/Budget, Time Trackeretc. These applications can be used in tablets not only to increase efficiency but also help teachers and students in organizing ideas, concepts and processes during project creation as well as in assigning tasks and time management (Schnackenberg, 2013). Both clikers and Classroom Presenter are among important classroom advancements (Roschelle, Tatar, Chaudhury, Dimitriadis, Patton and DiGiano, 2007). There are many other applications and researchers carry out trials with these applications to examine their effectiveness on classroom use.

When tablet related studies are examined, it was asserted that many benefits observed for both students and teachers for classroom use. Lim (2011) states that texts prepared directly on digital screens of the tablets are much more efficient in comparison with writing on the board and preparing power point slides. In addition, digital ink takes the place of pen and paper in education to enable teachers completing and sending back hand written feedback digitally ( $\mathrm{Li}$ and Akahori, 2007). In this regard, it can be stated that increase in teacher efficiency when acquiring student evaluation data, authentic learning environment, creation of more active environments and internet access are among the benefits of tablets (Nye, 2010). In addition, mobile devices provide opportunities for fast data acquisition, organization and data exchange as put forth by Avraamidou (2008). Tablets encourage teaching to be adapted for applications and participation (Roschelle et al., 2007) while attracting the students to the course by using digital ink as teaching material (Gorgievski, Stroud, Truxaw and DeFranco, 2005). It can also be stated that tablet use has various benefits for courses as well. For example, analysis and solution of problems that require mathematical formulations, diagrams and sketches make tablets more suited in comparison with laptop computers (Enriquez, 2009). Tablets provide students with an environment for text, graphics, sound, video, picture, animation and simulation (Tekbiyik and Akdeniz, 2010). As can be understood, it can be stated that the use of tablets in classes has many benefits for both students and teachers.

The literature review reveals that there are studies on the use of tablets in education-teaching environments. Avraamidou (2008) carried out a literature review study on expectations regarding the use of mobile technologies in science education, whereas Cao (2014) carried out a literature review study on the use of tablet technology to create an interactive classroom environment. In addition, Cicchino and Mirliss (2004) carried out a literature review study on tablets as a teaching tool whereas Schnackenberg (2013) carried out a literature review study related with education and tablet technology. Willis and Miertschin (2004) carried out a study on the use of Tablet PC as a teaching tool in which they shared their experiences at the Faculty in the College of Technology at the University of Houston. Ozkale and Koc (2014) carried out a literature review study related with the use of tablet computers in teaching environments. When these studies are examined, it is understood that in general they contain theoretical information on tablet use and application areas. In these studies, the author gives the information about tablets which is not research findings. They define the tablet application, tablets and education, tablets in classroom etc. Therefore, there can be said that there is no article includes research results on the use of tablets in science education. In the literature Sheehy et al. (2005) emphasized in their study that the key findings of the review of projects in which Tablet PC's are used as well as the literature review. When this study is examined, it can be said that a limited number of articles were included in the study. In addition, this study was carried out in 2005 and new and current studies are needed in the literature. It can also be added that there are limited number of studies which contains a detailed analysis. It can also be added that no study was found which contains a detailed examination and analysis of the studies carried out in this field. In this regard, it can be stated that there is a need for a study which reviews the research articles on tablet use in science education.

It can be stated that the review and analysis of articles are important which published at the national and international levels, proceedings and theses on tablets. Because, the study carried out is important for presenting the current status to the researchers, giving a direction regarding shortcomings and providing new ideas. It can 
be stated that review studies which are related with approaches or tools that have started to gain importance recently as well as those that are open to research in the field are especially important. In parallel with the limited number of relevant studies in international literature, studies and applications carried out in Turkey on educational tablet use is still at a beginning stage (Cuhadar, 2014). In this regard, it is thought that carrying out a review and analysis on the studies related with tablet use in science education will be important for researchers, teachers, curriculum developers and policy makers.

The aim of the study was to carry out an analysis of the studies on tablet use in science education regarding general features, rationales, aims, research methods, samples, results and suggestions. The focus questions for our review of the literature are as follows:

1. What are the rationales behind the use of tablets in science education?

2. What are the aims of the studies regarding the use of tablets in science education?

3. What research methods, samples, instruments, applications and concepts are used in the studies regarding the use of tablets in science education?

4. What are the results of the studies regarding of tablets in science education?

5. What are the suggestions for researchers, teachers, curriculum developers and policy makers regarding the use of tablets in science education?

\section{Method}

In this study, a thematic review of the studies was presented on tablet use in science education. Literature review is the examination of visual and auditory pieces such as articles, documents, maps, pictures, photographs on the related topic (Cepni, 2014). Whereas, the thematic review should emphasize how learning and teaching will develop as well as questions on the practicality of the suggestions made and the accomplishments (Ultay and Calik, 2012). Thematic matrix should be used to define every study, emphasize general trends, explain similarities and differences and indicate the unique features of each study (Calik, Ayas and Ebenezer, 2005; Kurnaz and Calik, 2009).

Table 1. Distribution of studies by types

\begin{tabular}{|c|c|c|c|c|c|}
\hline Name & Types & $\mathrm{f}$ & Types & $\mathrm{f}$ & f \\
\hline Computers \& Education & Journal & 2 & \multirow{3}{*}{$\begin{array}{l}\text { International } \\
(\mathrm{SSCI} / \mathrm{SCI})\end{array}$} & \multirow{3}{*}{4} & \multirow{11}{*}{13} \\
\hline Advances in Physiology Education & Journal & 1 & & & \\
\hline Journal of Chemical Education & Journal & 1 & & & \\
\hline Mevlana International Journal of Education & Journal & 2 & \multirow{8}{*}{ International } & \multirow{8}{*}{9} & \\
\hline Cumhuriyet International Journal of Education & Journal & 1 & & & \\
\hline Interactive Technology and Smart Education & Journal & 1 & & & \\
\hline Kamla-Raj: International Journal of Educational Sciences & Journal & 1 & & & \\
\hline $\begin{array}{l}\text { Mustafa Kemal University Journal of Social Sciences } \\
\text { Institute }\end{array}$ & Journal & 1 & & & \\
\hline Journal of College Science Teaching & Journal & 1 & & & \\
\hline $\begin{array}{l}\text { Turkish Studies-International Periodical for the Languages } \\
\text { Literature and History of Turkish or Turkic }\end{array}$ & Journal & 1 & & & \\
\hline $\begin{array}{l}\text { Physics Education } \\
\end{array}$ & Journal & 1 & & & \\
\hline $\begin{array}{l}\text { World Conference on Educational Multimedia, Hypermedia } \\
\text { and Telecommunications }\end{array}$ & Conference & 2 & $\begin{array}{c}10 \text { years and } \\
\text { more than } \\
10 \text { years }\end{array}$ & 2 & \multirow{7}{*}{9} \\
\hline International Conference on Computer Supported Education & Conference & 2 & \multirow{6}{*}{$\begin{array}{l}\text { Less than } 10 \\
\text { years }\end{array}$} & \multirow{6}{*}{7} & \\
\hline $\begin{array}{l}\text { International Conference New Perspective in Science } \\
\text { Education }\end{array}$ & Conference & 1 & & & \\
\hline $\begin{array}{l}\text { International Technology, Education and Development } \\
\text { Conference }\end{array}$ & Conference & 1 & & & \\
\hline IEEE International Conference & Conference & 1 & & & \\
\hline AIP Conference & Conference & 1 & & & \\
\hline Frontiers in Education Conference & Conference & 1 & & & \\
\hline Doctoral Thesis & Thesis & 1 & \multirow{3}{*}{$\begin{array}{l}\text { Thesis/ } \\
\text { Book }\end{array}$} & \multirow{3}{*}{3} & \multirow{3}{*}{3} \\
\hline Master Thesis & Thesis & 1 & & & \\
\hline Book & Book & 1 & & & \\
\hline Total & & 25 & & 25 & 25 \\
\hline
\end{tabular}




\section{Sample and Data Collection}

Taylor \& Francis, Springer, Scopus, Science Direct, EBSCO, JSTOR, Web of Science, Wiley Online Library, Google Academy databases were examined within the scope of the study. In addition, the magazines were also reviewed including in the social sciences citation index (SSCI) which publish studies on technology or computer use. The studies related with tablet use in science education were tried to be downloaded as a result of the performed review work. Some studies could not be reached despite all efforts and some studies could not be obtained fully but only their abstracts. In this regard, this issue that occurred during database review can be specified as a limitation of the study.

The keywords "tablet/s" "tablet pc/s" and "science education", "science curriculum" or "science classroom" were entered into the database when reviewing the studies on tablet use in science education. 25 studies were found on tablet use in science education and these articles have been marked with an asterix $(*)$ in the references section. Table 1 showed the frequency values for the studies carried out on tablet use in science education. 13 studies published in international journals such as Computers \& Education, Advances in Physiology Education, Journal of Chemical Education, Mevlana International Journal of Education. In addition, nine studies presented in conferences whereas three studies published as part of a thesis or a book section.

Table 2. Frequencies of studies by years of studies

\begin{tabular}{cccccc}
\hline \multirow{2}{*}{ Years of Studies } & $\begin{array}{c}\text { SSCI/ SCI } \\
\text { f }\end{array}$ & $\begin{array}{c}\text { International } \\
\text { f }\end{array}$ & $\begin{array}{c}\text { Conference } \\
\text { f }\end{array}$ & $\begin{array}{c}\text { Thesis/Books } \\
\text { f }\end{array}$ & $\begin{array}{c}\text { Total } \\
\text { f }\end{array}$ \\
\hline 2014 & 2 & 3 & 1 & - & 6 \\
2013 & 1 & 3 & 3 & 2 & 9 \\
2012 & 1 & 2 & 1 & - & 4 \\
2011 & - & 1 & - & - & 1 \\
2010 & - & - & 1 & - & 1 \\
2009 & - & - & - & 1 & 1 \\
2008 & - & 1 & 1 & - & 2 \\
2007 & - & - & 1 & - & 1 \\
Total & 4 & 10 & 8 & 3 & 25 \\
\hline
\end{tabular}

Table 2 showed the frequency values for the distribution of studies by year. When we looked at Table 2, it was observed that one study each on tablet use in science education had been carried out in 2007, 2009, 2010 and 2011 whereas two studies had been carried out in 2008. It was observed that the number of studies was four in 2012, nine with a significant increase in 2013 and six in 2014.

Table 3. Frequencies of studies by number of authors

\begin{tabular}{cccccc}
\hline $\begin{array}{c}\text { Number } \\
\text { Authors }\end{array}$ & $\begin{array}{c}\text { SSCI/ SCI } \\
\mathrm{f}\end{array}$ & $\begin{array}{c}\text { International } \\
\mathrm{f}\end{array}$ & $\begin{array}{c}\text { Conference } \\
\mathrm{f}\end{array}$ & $\begin{array}{c}\text { Thesis/Books } \\
\text { f }\end{array}$ & $\begin{array}{r}\text { Total } \\
\mathrm{f}\end{array}$ \\
\hline 1 & 1 & - & - & 2 & 3 \\
2 & - & 4 & 2 & 1 & 7 \\
3 & 1 & 4 & 1 & - & 6 \\
4 & 1 & 1 & 1 & - & 3 \\
5 & - & - & 4 & - & 4 \\
6 & 1 & - & - & - & 1 \\
8 & - & - & 1 & - & 1 \\
Total & 4 & 9 & 9 & 3 & 25 \\
\hline
\end{tabular}

Table 3 showed the information related with the number of authors and Table 4 showed the information related with the frequencies of authors by nationality. When Table 3 was examined, it was observed that three studies had either one or four authors, seven studies had two authors and seven studies had three authors.

When Table 4 was examined, of the studies carried out on tablet use in science education seven studies had been carried out in Turkey, seven studies in the United States, three studies in Canada, two studies in the United Kingdom and two studies is Japan. Almost all the studies carried out by Turkish citizens had published in international journals. 
Table 4. Frequencies of studies by authors nationality

\begin{tabular}{lccccc}
\hline Authors & SSCI/ SCI & International & Conference & Thesis & Total \\
Nationality & $\mathrm{f}$ & $\mathrm{f}$ & $\mathrm{f}$ & $\mathrm{f}$ & $\mathrm{f}$ \\
\hline Turkey & - & 6 & 1 & - & 7 \\
United States & 3 & - & 3 & 1 & 7 \\
Canada & 1 & 1 & 1 & - & 3 \\
United Kingdom & 1 & 1 & - & - & 2 \\
Japan & - & - & 2 & - & 2 \\
The Netherlands & - & - & 1 & - & 1 \\
Italy & - & - & 1 & - & 1 \\
Sweden & - & - & - & 1 & 1 \\
Indiana & - & - & - & 1 & 1 \\
India & - & - & 1 & - & 1 \\
Finland & - & 1 & - & - & 1 \\
Total & 5 & 9 & 10 & 3 & 27 \\
\hline
\end{tabular}

\section{Data Analysis}

In this study, the matrix was used for the analysis of the studies. In this regard, the matrix developed by Ormanci, Cepni, Deveci and Aydin (2015) was used to analyze the studies related with tablet use in science education. The matrix used in this study includes two fundamental themes such as general features and content features. General features include types of journals, years of studies and demographic properties (number of authors and author nationality). These features used to portray the studies under investigation. Content features include rationales, aims, research methods, samples, data collections, results and suggestions. In addition, two additions were made to the method section of the matrix in this study to explain in more detail the tablet applications and the studies on scientific concepts. The final version of the matrix is given in Table 5.

Table 5. Matrix for a thematic review of the use if tablet PCs in science education

\begin{tabular}{|c|c|c|c|}
\hline Themes & Sub-Themes & & Explanations \\
\hline \multirow{4}{*}{$\begin{array}{l}\text { General } \\
\text { Features }\end{array}$} & Type of Studies & \multirow{3}{*}{ Properties } & Place and group of the publication (article, congress, etc.) \\
\hline & Demooranhic & & \\
\hline & (Number of Authors) & & Number of authors \\
\hline & $\begin{array}{l}\text { Demographic } \\
\text { (Author Nationality) }\end{array}$ & Properties & Nationality of the author \\
\hline \multirow{9}{*}{$\begin{array}{l}\text { Content } \\
\text { Features }\end{array}$} & Rationales & & Rationale of the study \\
\hline & Aims & & Main aim of the study \\
\hline & Research Methods & & $\begin{array}{l}\text { Qualitative (case study, action research, etc.), quantitative } \\
\text { (descriptive, survey, etc.) and others (mix methods, etc.) }\end{array}$ \\
\hline & Samples & & $\begin{array}{l}\text { Sample of the study (teacher, teacher candidate, student, } \\
\text { etc.) } \\
\text { and sample numbers (0-10,11-30,31-100, 101-200, } 201 \\
\text { and up) }\end{array}$ \\
\hline & Data Collections & & $\begin{array}{l}\text { Data collection of the study (interviews, observations, } \\
\text { survey etc.) }\end{array}$ \\
\hline & Applications & & $\begin{array}{l}\text { Application of the study (classroom presenter, DyKnow, } \\
\text { etc.) }\end{array}$ \\
\hline & Science Concepts & & The concept which is researched (electricity, gain etc.) \\
\hline & Results & & Main result of the study \\
\hline & Suggestions & & Main suggestion of the study \\
\hline
\end{tabular}

The acquired data were analyzed via descriptive statistical methods (percentage and frequency) and content analysis method. Descriptive analysis was generally used for the general properties of the matrix whereas content analysis was used for the content properties of the matrix. Data acquired from the studies were first transformed into codes during content analysis after which suitable codes were combined to create themes. Frequency and $\%$ values were calculated for the generated codes and themes. In the study, the studies were examined by two researchers in order to ensure the validity and reliability of the study. The unstable places in the analysis were decided by two researchers. 


\section{Results}

This section of the study contains results regarding content features (rationales, aims, research methods, samples, data collections, applications, science concepts, results and suggestions.).

\section{What are the rationales behind the use of tablets in science education?}

The frequency and percentage distribution values regarding the rationales of studies on tablet use in science education were showed in Table 6.

Table 6 . Frequencies of studies by rationales

\begin{tabular}{|c|c|c|c|c|c|c|c|c|}
\hline & & Rationale & & & & & & \\
\hline Theme & Sub-Theme & Code & $\mathrm{f}$ & $\%$ & $\mathrm{f}$ & $\%$ & $\mathrm{f}$ & $\%$ \\
\hline \multirow{7}{*}{$\begin{array}{l}\text { Science } \\
\text { related }\end{array}$} & \multirow[b]{2}{*}{$\begin{array}{l}\text { Shortcoming } \\
\text { in the Field }\end{array}$} & Low number of studies on tablets & 1 & 5.3 & \multirow[b]{2}{*}{3} & \multirow[b]{2}{*}{15.8} & \multirow{7}{*}{8} & \multirow{7}{*}{42.1} \\
\hline & & $\begin{array}{l}\text { The fact that its effect on learning process } \\
\text { cannot be determined even though it is an } \\
\text { education tool } \\
\text { The need for studies on the effects of } \\
\text { tablets on learning attitudes }\end{array}$ & 1 & 5.3 & & & & \\
\hline & \multirow{5}{*}{$\begin{array}{l}\text { Material } \\
\text { Change }\end{array}$} & $\begin{array}{l}\text { Lack of material related with teacher } \\
\text { education for tablets }\end{array}$ & 1 & 5.3 & \multirow{5}{*}{5} & \multirow{5}{*}{26.3} & & \\
\hline & & $\begin{array}{l}\text { The fact that computer simulations have a } \\
\text { significant space in teaching concepts }\end{array}$ & 1 & 5.3 & & & & \\
\hline & & $\begin{array}{l}\text { Difficulties in making selections due to the } \\
\text { large number of applications in the field }\end{array}$ & 1 & 5.3 & & & & \\
\hline & & $\begin{array}{l}\text { Importance of the use of computer aided } \\
\text { visual material }\end{array}$ & 1 & 5.3 & & & & \\
\hline & & $\begin{array}{l}\text { Necessity of new technologies to establish } \\
\text { classes for research/questioning }\end{array}$ & 1 & 5.3 & & & & \\
\hline \multirow{12}{*}{ General } & \multirow{4}{*}{$\begin{array}{l}\text { Shortcoming } \\
\text { in the Field }\end{array}$} & Low number of studies on tablets & 1 & 5.3 & \multirow{4}{*}{4} & \multirow{4}{*}{21.1} & \multirow{11}{*}{11} & \multirow{11}{*}{57.9} \\
\hline & & $\begin{array}{l}\text { Necessity of integrating tablets with new } \\
\text { learning methods }\end{array}$ & 1 & 5.3 & & & & \\
\hline & & $\begin{array}{l}\text { Importance of student opinions about the } \\
\text { topic }\end{array}$ & 1 & 5.3 & & & & \\
\hline & & $\begin{array}{l}\text { Importance of the opinions of teachers as } \\
\text { the appliers }\end{array}$ & 1 & 5.3 & & & & \\
\hline & \multirow{7}{*}{$\begin{array}{l}\text { Positive } \\
\text { Effects on } \\
\text { Teaching } \\
\text { Environment }\end{array}$} & Increased use of tablets in education & 1 & 5.3 & \multirow{4}{*}{4} & \multirow{4}{*}{21.1} & & \\
\hline & & Increase of tablet use among students & 1 & 5.3 & & & & \\
\hline & & Increase of the use of digital books & 1 & 5.3 & & & & \\
\hline & & Increase of technology in the classrooms & 1 & 5.3 & & & & \\
\hline & & $\begin{array}{l}\text { The fact that tablets provide an increase in } \\
\text { student learning }\end{array}$ & 1 & 5.3 & \multirow{3}{*}{3} & \multirow{3}{*}{15.8} & & \\
\hline & & $\begin{array}{l}\text { The fact that its use related with student } \\
\text { activity and learning positivity increases }\end{array}$ & 1 & 5.3 & & & & \\
\hline & & $\begin{array}{l}\text { The positive effects of new technologies } \\
\text { on students, teachers and the classroom } \\
\text { environment }\end{array}$ & 1 & 5.3 & & & & \\
\hline & \multicolumn{2}{|l|}{ Total* } & 19 & 100.0 & 19 & 100.0 & 19 & 100.0 \\
\hline
\end{tabular}

Table 6 showed the rationales for studies related with tablet use in science education and the rationales were classified under two main themes with respect to whether a relationship with science established or not. Rationales related with science were classified under shortcomings in the field and material change, whereas general rationales were classified under sub-themes of shortcomings in the field, innovation and the positive effect on innovation and learning environment. It was asserted that $\% 5.3$ of the studies carried out due to the fact that the number of studies on tablets is low with whereas the percentage for the lack of materials related with teacher material on tablets was \%5.3, the percentage for the increased popularity of tablet use in education was $\% 5.3$, and the percentage for the increase in student learning caused by tablet use was \%5.3. 
2. What are the aims of the studies regarding the use of tablets in science education?

The frequency and percentage values for the aims of the studies carried out in science education using tablets were showed in Table 7.

Table 7. Frequencies of studies by aims

\begin{tabular}{|c|c|c|c|c|c|}
\hline & Aims & & & & \\
\hline Theme & Code & $\mathrm{f}$ & $\%$ & $\mathrm{f}$ & $\%$ \\
\hline \multirow{8}{*}{ Effectiveness } & Examining the effect on the student & 3 & 9.8 & \multirow{8}{*}{12} & \multirow{8}{*}{38.7} \\
\hline & Examining the effect on student performance & 2 & 6.5 & & \\
\hline & Examining the effectiveness of tablet material & 2 & 6.5 & & \\
\hline & Examining the effect on teachers & 1 & 3.2 & & \\
\hline & Examining the effect on learning gains & 1 & 3.2 & & \\
\hline & Examining the effect on learning outputs & 1 & 3.2 & & \\
\hline & Examining the effect on student success & 1 & 3.2 & & \\
\hline & Examining the effect on student attitude & 1 & 3.2 & & \\
\hline \multirow{6}{*}{ Case report } & Taking teacher opinions on tablets & 2 & 6.5 & \multirow{6}{*}{7} & \multirow{6}{*}{22.6} \\
\hline & Taking student opinions on tablets & 1 & 3.2 & & \\
\hline & Examining experiences related with tablet use & 1 & 3.2 & & \\
\hline & $\begin{array}{l}\text { Examining tablet use in drawing and } \\
\text { discussion environments }\end{array}$ & 1 & 3.2 & & \\
\hline & $\begin{array}{l}\text { Examining the use to archive student } \\
\text { homework }\end{array}$ & 1 & 3.2 & & \\
\hline & $\begin{array}{l}\text { Examining the use to attract the attention of } \\
\text { students }\end{array}$ & 1 & 3.2 & & \\
\hline \multirow{4}{*}{$\begin{array}{l}\text { Material } \\
\text { Development }\end{array}$} & Developing tablet applications & 4 & 12.9 & \multirow{4}{*}{7} & \multirow{4}{*}{22.6} \\
\hline & $\begin{array}{l}\text { Developing a rubric related with mobile } \\
\text { science applications }\end{array}$ & 1 & 3.2 & & \\
\hline & $\begin{array}{l}\text { Developing course books that are suited to } \\
\text { tablet use }\end{array}$ & 1 & 3.2 & & \\
\hline & Developing tablet related materials & 1 & 3.2 & & \\
\hline \multirow{4}{*}{ Attitude } & $\begin{array}{l}\text { Examining the attitudes of students towards } \\
\text { technology in tablet applications }\end{array}$ & 2 & 6.5 & \multirow{4}{*}{5} & \multirow{4}{*}{16.1} \\
\hline & $\begin{array}{l}\text { Developing an attitude scale for tablet } \\
\text { applications }\end{array}$ & 1 & 3.2 & & \\
\hline & $\begin{array}{l}\text { Examining the attitudes of parents towards } \\
\text { tablet applications }\end{array}$ & 1 & 3.2 & & \\
\hline & $\begin{array}{l}\text { Examining the attitudes of teachers towards } \\
\text { tablet applications }\end{array}$ & 1 & 3.2 & & \\
\hline Total* & & 31 & 100.0 & 31 & 100.0 \\
\hline
\end{tabular}

When Table 7 was examined, it can be observed that the relevant studies was collected under the themes of status determination, material development and related with attitude. It is observed that $\% 9.8$ of the studies examine the effects on students, $\% 6.5$ of the studies examine the effects on student performance and $\% 6.5$ of the studies examine the effectiveness of the tablet material. In addition, it is observed that $\% 6.5$ of the studies in the literature examine the attitudes of students towards technology in tablet applications and \%6.5 of the studies include attitudes of teachers regarding tablets. In addition, \%12.9 of the studies in literature aims to develop tablet applications.

3. What research methods, samples, instruments and applications are used in the studies regarding the use of tablets in science education?

The frequency and percentage values of the methods used in studies regarding the use of tablets in science education were showed in Table 8. 
Table 8 . Frequencies of studies by methods

\begin{tabular}{|c|c|c|c|c|c|c|c|c|c|c|}
\hline \multirow{2}{*}{ Methods } & \multicolumn{2}{|c|}{$\mathrm{SSCI} / \mathrm{SCI}$} & \multicolumn{2}{|c|}{ International } & \multicolumn{2}{|c|}{ Conference } & \multicolumn{2}{|c|}{$\begin{array}{l}\text { Thesis/ } \\
\text { Books }\end{array}$} & \multicolumn{2}{|c|}{ Total* } \\
\hline & $\mathrm{f}$ & $\%$ & $\mathrm{f}$ & $\%$ & $\mathrm{f}$ & $\%$ & $\mathrm{f}$ & $\%$ & $\mathrm{f}$ & $\%$ \\
\hline $\begin{array}{l}\text { Experimental/empirical } \\
\text { method }\end{array}$ & 1 & 4.5 & 2 & 9.1 & 3 & 13.6 & 2 & 9.1 & 8 & 36.4 \\
\hline Descriptive survey & - & - & 3 & 13.6 & - & - & - & - & 3 & 13.6 \\
\hline Case study & - & - & - & - & 3 & 13.6 & - & - & 3 & 13.6 \\
\hline Survey method & - & - & 2 & 9.1 & - & - & - & - & 2 & 9.1 \\
\hline Mixed method & 1 & 4.5 & - & - & - & - & - & - & 1 & 4.5 \\
\hline Controlled study & 1 & 4.5 & - & - & - & - & - & - & 1 & 4.5 \\
\hline Comparison method & - & - & 1 & 4.5 & - & - & - & - & 1 & 4.5 \\
\hline Improving apps & - & - & - & - & 1 & 4.5 & - & - & 1 & 4.5 \\
\hline Modified Delphi study & - & - & - & - & 1 & 4.5 & - & - & 1 & 4.5 \\
\hline Scale development & - & - & 1 & 4.5 & - & - & - & - & 1 & 4.5 \\
\hline Total & 3 & 13.6 & 9 & 40.9 & 8 & 36.4 & 2 & 9.1 & 22 & 100.0 \\
\hline
\end{tabular}

When Table 8 was examined, it can be observed that $\% 36.4$ of the studies used the frequently experimental/empirical method, $\% 13.6$ of the studies used the descriptive survey or the case study method and that $\% 9.1$ of the studies used the survey method. It is understood that journals within the scope of SSCI/SCI used experimental/empirical method, mixed method or controlled study, whereas international journals used experimental method, descriptive survey, survey method. In addition, it was determined that some studies had not specified the used methods. The frequency and percentage values related with the variables or themes in the studies were showed in Table 9.

Table 9. Distribution of studies by variables or themes

\begin{tabular}{|c|c|c|c|c|c|c|c|c|c|c|c|}
\hline & \multirow[t]{2}{*}{ Variables } & \multicolumn{2}{|c|}{$\begin{array}{l}\text { SSCI/ } \\
\text { SCI }\end{array}$} & \multicolumn{2}{|c|}{ International } & \multicolumn{2}{|c|}{ Conference } & \multicolumn{2}{|c|}{$\begin{array}{l}\text { Thesis/ } \\
\text { Books }\end{array}$} & \multicolumn{2}{|c|}{ Total* } \\
\hline & & $\mathrm{f}$ & $\%$ & $\mathrm{f}$ & $\%$ & $\mathrm{f}$ & $\%$ & $\mathrm{f}$ & $\%$ & $\mathrm{f}$ & $\%$ \\
\hline \multirow{6}{*}{ 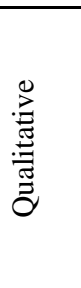 } & Taking general opinions & - & - & 3 & 10.4 & - & - & - & - & 3 & 10.4 \\
\hline & Examining the status of use & - & - & - & - & 2 & 6.9 & - & - & 2 & 6.9 \\
\hline & $\begin{array}{l}\text { Examining the learning } \\
\text { environment }\end{array}$ & - & - & - & - & 1 & 3.5 & - & - & 1 & 3.5 \\
\hline & Examining the effectiveness & - & - & - & - & 1 & 3.5 & - & - & 1 & 3.5 \\
\hline & Examining the system & - & - & - & - & 1 & 3.5 & - & - & 1 & 3.5 \\
\hline & Taking the opinions regarding use & - & - & 1 & 3.5 & - & - & - & - & 1 & 3.5 \\
\hline \multirow{9}{*}{ 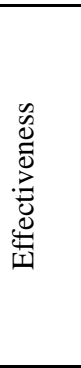 } & Effect on attitude & 1 & 3.5 & 3 & 10.4 & - & - & - & - & 4 & 13.8 \\
\hline & Effect on learning & - & - & - & - & 1 & 3.5 & 1 & 3.5 & 2 & 6.9 \\
\hline & Effect on concept & - & - & - & - & 1 & 3.5 & 1 & 3.5 & 2 & 6.9 \\
\hline & Effect on perception & - & - & - & - & 1 & 3.5 & 1 & 3.5 & 2 & 6.9 \\
\hline & Understanding/misconception & 1 & 3.5 & - & - & - & - & - & - & 1 & 3.5 \\
\hline & Effect on outcome & - & - & - & - & 1 & 3.5 & - & - & 1 & 3.5 \\
\hline & Effect on behavior & 1 & 3.5 & - & - & - & - & - & - & 1 & 3.5 \\
\hline & Effect on motivation & - & - & - & - & - & - & 1 & 3.5 & 1 & 3.5 \\
\hline & Effect on knowledge & - & - & - & - & - & - & 1 & 3.5 & 1 & 3.5 \\
\hline \multirow{5}{*}{ 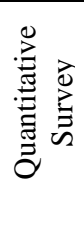 } & Performance determination & 1 & 3.5 & 1 & 3.5 & - & - & - & - & 2 & 6.9 \\
\hline & Determination of use & 1 & 3.5 & - & - & - & - & - & - & 1 & 3.5 \\
\hline & $\begin{array}{l}\text { Examining technology use and } \\
\text { its reasons }\end{array}$ & - & - & 1 & 3.5 & - & - & - & - & 1 & 3.5 \\
\hline & Determining attitudes & - & - & 1 & 3.5 & - & - & - & - & 1 & 3.5 \\
\hline & Total & 5 & 17.2 & 10 & 34.5 & 9 & 31.0 & 5 & 17.2 & 29 & 100 \\
\hline
\end{tabular}

When Table 9 was examined, it can be observed that the number of qualitative studies was very low and general opinions were taken with a frequency of \%10.4. In addition, the effectiveness of tablet use on some variables were examined in many of the studies. Studies in literature had examined the effects on attitude with a frequency of \%13.8, on learning with a frequency of \%6.9, on concept with a frequency of $\% 6.9$ and on perception with a frequency of \%6.9. In addition, it is observed that studies in journals within the scope of SSCI/SCI determined the status related with tablets and its effects on some variables were examined. 
The data related with the numbers of study groups or samples in the analyzed studies showed in Table 10 while Table 11 contained data related with type.

Table 10. Frequencies of studies by number of samples

\begin{tabular}{|c|c|c|c|c|c|c|c|c|c|c|}
\hline \multirow[t]{2}{*}{ Number of Samples } & \multicolumn{2}{|c|}{$\mathrm{SSCI} / \mathrm{SCI}$} & \multicolumn{2}{|c|}{ International } & \multicolumn{2}{|c|}{ Conference } & \multicolumn{2}{|c|}{$\begin{array}{l}\text { Thesis/ } \\
\text { Books }\end{array}$} & \multicolumn{2}{|c|}{ Total* } \\
\hline & $\mathrm{f}$ & $\%$ & $\mathrm{f}$ & $\%$ & $\mathrm{f}$ & $\%$ & $f$ & $\%$ & $\mathrm{f}$ & $\%$ \\
\hline $0-30$ & 1 & 4.6 & - & - & 2 & 9.1 & - & - & 3 & 13.6 \\
\hline $31-100$ & 1 & 4.6 & 3 & 13.6 & 4 & 18.2 & - & - & 8 & 36.4 \\
\hline $101-200$ & 2 & 9.1 & 4 & 18.2 & 2 & 9.1 & - & - & 8 & 36.4 \\
\hline 201 and more than & - & - & 2 & 9.1 & - & - & 1 & 4.6 & 3 & 13.6 \\
\hline Total & 4 & 18.2 & 9 & 40.9 & 8 & 36.4 & 1 & 4.6 & 22 & 100.0 \\
\hline
\end{tabular}

Table 11. Frequencies of studies by type of samples

\begin{tabular}{|c|c|c|c|c|c|c|c|c|c|c|}
\hline \multirow[t]{2}{*}{ Type of Samples } & \multicolumn{2}{|c|}{$\mathrm{SSCI} / \mathrm{SCI}$} & \multicolumn{2}{|c|}{ International } & \multicolumn{2}{|c|}{ Conference } & \multicolumn{2}{|c|}{$\begin{array}{l}\text { Thesis/ } \\
\text { Books }\end{array}$} & \multicolumn{2}{|c|}{ Total* } \\
\hline & $\mathrm{f}$ & $\%$ & $\mathrm{f}$ & $\%$ & $\mathrm{f}$ & $\%$ & $\mathrm{f}$ & $\%$ & $\mathrm{f}$ & $\%$ \\
\hline Student & 1 & 4.2 & 4 & 16.7 & 5 & 20.8 & 2 & 8.3 & 12 & 50.0 \\
\hline Pre-service teacher & 2 & 8.3 & 3 & 12.5 & 2 & 8.3 & - & - & 7 & 29.2 \\
\hline Teacher & 1 & 4.2 & 2 & 8.3 & - & - & 1 & 4.2 & 4 & 16.7 \\
\hline Department** & - & - & - & - & - & - & 1 & 4.2 & 1 & 4.2 \\
\hline Total & 4 & 16.7 & 9 & 37.5 & 7 & 29.2 & 4 & 16.7 & 24 & 100.0 \\
\hline
\end{tabular}

When the study group and samples in the studies were examined, it was observed that the frequency of studies published in SSCI journals carried out with 0-30 or 31-100 people was \%4.6 whereas the frequency of studies carried out with 101-200 was \%9.1. Whereas the frequency of studies carried out with 101-200 people and published in international journals was \%18.2 and the frequency of studies carried out with 31-100 people was $\%$ 13.6. In general, it can be observed that the frequency of working with 31-100 participants was \%36.4 frequently and that the frequency of working with 101-200 participants was \%36.4. In the sample types, studies in SSCI scope were carried out with pre-service teachers with a frequency of \%8.3. The frequency of studies published in international journals carried out with students was \% 16.7 , the frequency of studies carried out with pre-service teachers was \%12.5. The frequency of studies carried out with teachers was $\% 8.3$ and the frequencies for students and pre-service teachers in conferences were $\% 20.8$ and $\% 8.3$ respectively. In this regard, studies were generally carried out with students with a frequency of $\% 50.0$ whereas the frequency of studies carried out with pre-service teachers was \%29.2. The values related with frequencies and percentages related with data acquisition instruments can be seen in Table 12.

Table 12. Frequencies of studies by type of instruments

\begin{tabular}{|c|c|c|c|c|c|c|c|c|c|c|}
\hline \multirow[t]{2}{*}{ Type of Samples } & \multicolumn{2}{|c|}{$\mathrm{SSCI} / \mathrm{SCI}$} & \multicolumn{2}{|c|}{ International } & \multicolumn{2}{|c|}{ Conference } & \multicolumn{2}{|c|}{$\begin{array}{l}\text { Thesis/ } \\
\text { Books }\end{array}$} & \multicolumn{2}{|c|}{ Total } \\
\hline & $\mathrm{f}$ & $\%$ & $\mathrm{f}$ & $\%$ & $\mathrm{f}$ & $\%$ & $\mathrm{f}$ & $\%$ & $f$ & $\%$ \\
\hline Likert type scale & 2 & 4.3 & 5 & 10.6 & 3 & 6.4 & 1 & 2.1 & 11 & 23.4 \\
\hline Questionnaire & 2 & 4.3 & 2 & 4.3 & 3 & 6.4 & - & - & 7 & 14.9 \\
\hline Open ended question & - & - & 3 & 6.4 & 2 & 4.3 & 1 & 2.1 & 6 & 12.8 \\
\hline Multiple choice test & 1 & 2.1 & 1 & 2.1 & 2 & 4.3 & 2 & 4.3 & 6 & 12.8 \\
\hline Observation & 1 & 2.1 & 2 & 4.3 & 1 & 2.1 & - & - & 4 & 8.5 \\
\hline Closed ended question & - & - & 3 & 6.4 & - & - & - & - & 3 & 6.4 \\
\hline Interview & - & - & 1 & 2.1 & 2 & 4.3 & - & - & 3 & 6.4 \\
\hline Puzzle & - & - & - & - & 1 & 2.1 & - & - & 1 & 2.1 \\
\hline Video recording & - & - & - & - & - & - & 1 & 2.1 & 1 & 2.1 \\
\hline Online homework & 1 & 2.1 & - & - & - & - & - & - & 1 & 2.1 \\
\hline Standard exam & 1 & 2.1 & - & - & - & - & - & - & 1 & 2.1 \\
\hline Rubric & 1 & 2.1 & - & - & - & - & - & - & 1 & 2.1 \\
\hline Reflective note & - & - & - & - & 1 & 2.1 & - & - & 1 & 2.1 \\
\hline Drawing & - & - & 1 & 2.1 & - & - & - & - & 1 & 2.1 \\
\hline Total* & 9 & 19.1 & 18 & 38.3 & 15 & 31.9 & 5 & 10.6 & 47 & 100.0 \\
\hline
\end{tabular}


The frequencies of instruments in the studies carried out were $\% 23.4, \% 14.9, \% 12.8$ in likert type scale, questionnaire, open ended question or multiple-choice test respectively. It was observed in the carried out studies within the scope of SSCI that the frequencies were $\% 4.3$ for likert type scale or questionnaire and $\% 2.1$ for multiple-choice test, observation, online homework, standard exam or rubric. When the international studies were examined, it was observed that the frequency of likert type scale was \%10.6 and the frequency for open ended question or closed ended question data acquisition instruments was \%6.4. The frequency and percentage values for applications used in tablet applications in science education showed in Table 13.

Table 13. Frequencies of studies by application

\begin{tabular}{lll}
\hline Application & f & $\%$ \\
\hline Windows Journal & 2 & 8.7 \\
DyKnow Vision software & 2 & 8.7 \\
Classroom presenter & 1 & 4.4 \\
Classroom management system & 1 & 4.4 \\
Ubiquitous presenter & 1 & 4.4 \\
Clickers & 1 & 4.4 \\
InkSurvey & 1 & 4.4 \\
Case method teaching material manga (web browser) & 1 & 4.4 \\
Case method teaching material manga (e-book) & 1 & 4.4 \\
Power point & 1 & 4.4 \\
Youtube & 1 & 4.4 \\
GearSketch learning environment & 1 & 4.4 \\
The App CLAST & 1 & 4.4 \\
The online labs (OLabs) & 1 & 4.4 \\
SimPad & 1 & 4.4 \\
One-Note & 1 & 4.4 \\
Input Panel & 1 & 4.4 \\
Tegrity lecture capture panle & 1 & 4.4 \\
Sapling Learning & 1 & 4.4 \\
SolarWalk app & 1 & 4.4 \\
Educreations & 1 & 4.4 \\
Total* & 23 & 100.0 \\
\hline ce some studies did not give applications, the total number is not equal to the number of articles.
\end{tabular}

Standard applications for tablets had been used in some studies in literature whereas applications developed by the researchers had been used in others and relevant studies had been carried out for these. It was observed that the frequencies of Windows Journal and DyKnowVisionsoftware were both \%8.7 in the studies using tablet applications. In addition, it can be observed that applications such as Classroompresenter, InkSurvey, Case method teaching material manga, TheApp CLAST are used with a frequency of $\% 4.4$.

The frequency and percentage values related with the concepts of science examined during tablet studies in science education showed in Table 14. Whereas the images in studies related with science concepts were indicated in Figures 1 and 2.

Table 14. Frequencies of studies by science concept

\begin{tabular}{lll}
\hline Science Concept & f & $\%$ \\
\hline Electricity & 3 & 17.1 \\
Chemistry concept / course & 2 & 11.8 \\
Biological course/ lab & 2 & 11.8 \\
Physical concept/ course & 2 & 11.8 \\
Magnetism & 1 & 5.9 \\
Atomic physics & 1 & 5.9 \\
Gear and chain systems & 1 & 5.9 \\
Climate & 1 & 5.9 \\
Science laboratory & 1 & 5.9 \\
Science course & 1 & 5.9 \\
Solar environment & 1 & 5.9 \\
Kinetic theory of gases & 1 & 5.9 \\
Total* & 17 & 100.0 \\
\hline ome studies did not give science concepts, the total number is not equal to the number of articles.
\end{tabular}




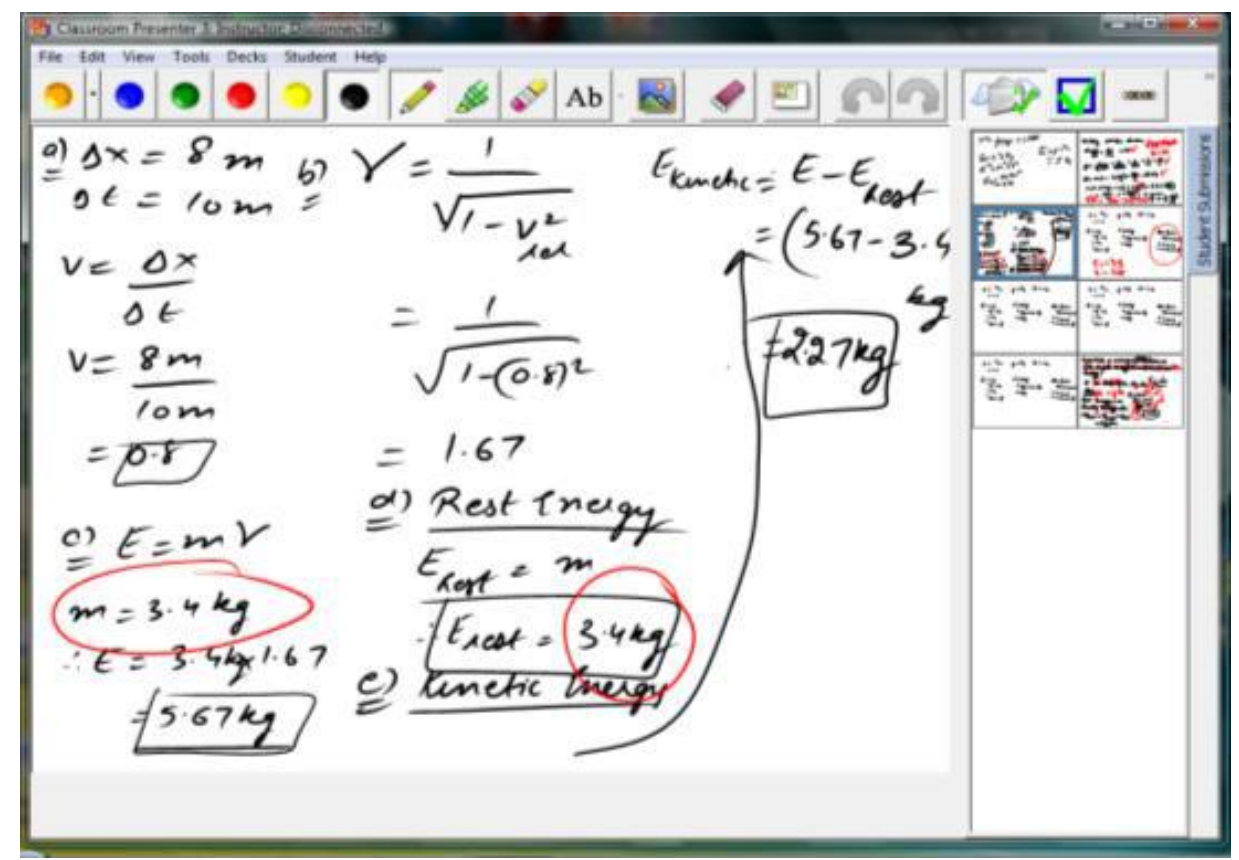

Figure 1. A screen shot from the teaching process of electricity and magnetism (Antimirova \& Milner-Bolotin, 2010)
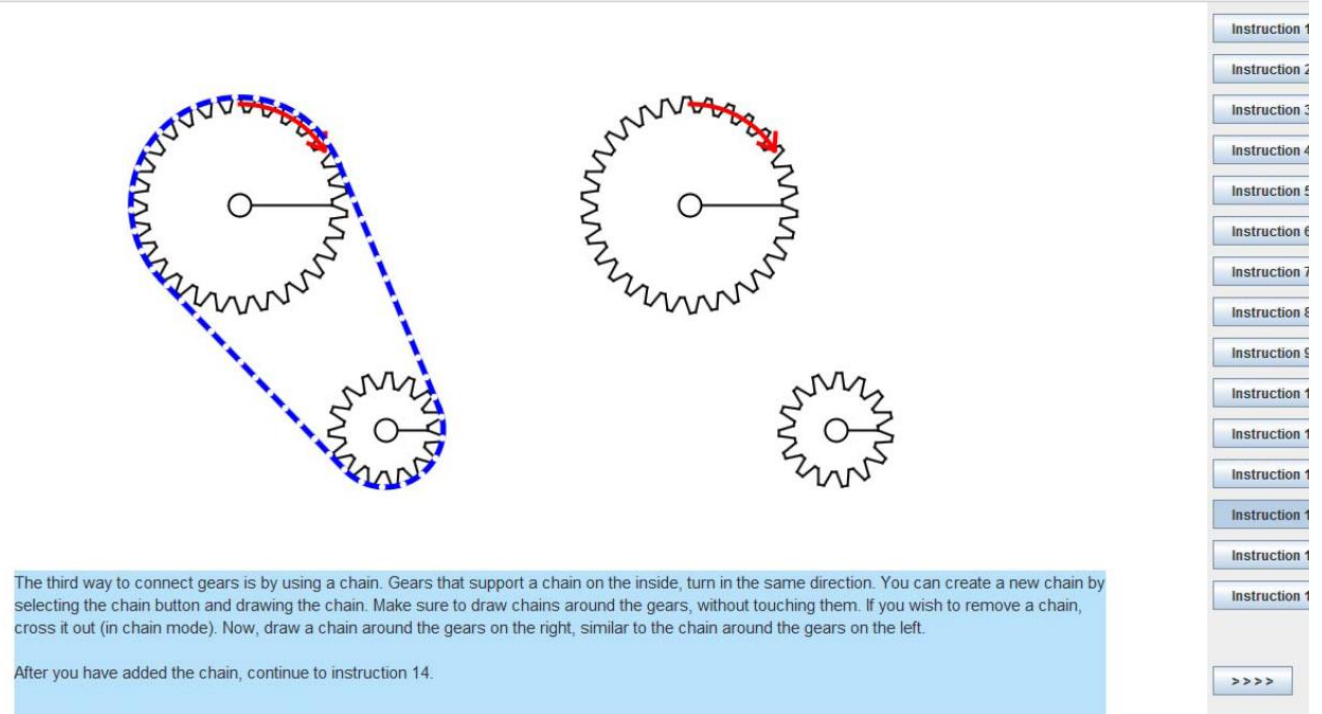

Figure 2. A screenshot from the teaching process of Gear and chain systems topic (Leenaars, vanJoolingen, Gijlers \& Bollen, 2012)

As seen in Table 14, it can be observed that the tablets had been used in science education with a frequency of $\% 17.1$ for the electricity topic, \%11.8 during chemistry concepts/course, \%11.8 during biology lesson/laboratory and \%11.8 during physics classes. In addition, it can be observed that studies had been carried out on topics such as magnetism, atomic physics, gear and chain systems. Of these, the screen shots related with the teaching processes of electricity and gear and chain system were given in Figures 1 and 2. However, in some of the studies indicated that done in science labs or science class, it did not focus on a science subject. In addition, some of the qualitative (such as taking general opinions) and survey (determining attitudes) studies could not focus on a certain science concept and thus they could not be examined regarding to this variable.

\section{What are the results of the studies regarding of tablets in science education?}

The frequency and percentage values related with the results acquired from studies carried out on tablet use in science education was presented in Table 15. 
Table 15. Frequencies of studies by results

\begin{tabular}{|c|c|c|c|c|c|}
\hline & Results & & & & \\
\hline Theme & Code & $\mathrm{f}$ & $\%$ & $\mathrm{f}$ & $\%$ \\
\hline \multirow{7}{*}{$\begin{array}{l}\text { Effect on } \\
\text { cognitive } \\
\text { properties }\end{array}$} & Helps learning & 3 & 12.0 & \multirow{7}{*}{12} & \multirow{7}{*}{48.0} \\
\hline & As an effective learning tool & 2 & 8.0 & & \\
\hline & Increases student performance & 2 & 8.0 & & \\
\hline & Increases products of learning & 2 & 8.0 & & \\
\hline & Increases learning opportunities & 1 & 4.0 & & \\
\hline & Having a positive impact on participants & 1 & 4.0 & & \\
\hline & Increasing learning effectiveness & 1 & 4.0 & & \\
\hline \multirow{7}{*}{$\begin{array}{l}\text { Effects on } \\
\text { use }\end{array}$} & $\begin{array}{l}\text { Provides positive attitude towards the use of } \\
\text { technology }\end{array}$ & 1 & 4.0 & \multirow{7}{*}{7} & \multirow{7}{*}{28.0} \\
\hline & $\begin{array}{l}\text { Increases the attitudes of parents of students who } \\
\text { use tablets during lessons }\end{array}$ & 1 & 4.0 & & \\
\hline & $\begin{array}{l}\text { Positively increases the attitudes towards tablet } \\
\text { use }\end{array}$ & 1 & 4.0 & & \\
\hline & Use of tablets as note taking devices & 1 & 4.0 & & \\
\hline & Teachers supporting the use of tablets in class & 1 & 4.0 & & \\
\hline & That e-books are an innovation & 1 & 4.0 & & \\
\hline & $\begin{array}{l}\text { Establishing a framework for the evaluation of } \\
\text { applications in science education }\end{array}$ & 1 & 4.0 & & \\
\hline \multirow{4}{*}{$\begin{array}{l}\text { Effects on } \\
\text { affective } \\
\text { properties }\end{array}$} & Making lessons more fun & 2 & 8.0 & \multirow{4}{*}{6} & \multirow{4}{*}{24.0} \\
\hline & Increasing the motivation/interest of students & 2 & 8.0 & & \\
\hline & Ensuring the visualization of complex materials & 1 & 4.0 & & \\
\hline & Enjoyed by students & 1 & 4.0 & & \\
\hline Total & & 25 & 100.0 & 25 & 100.0 \\
\hline
\end{tabular}

Table 15 was included data related with the results obtained from the studies on tablet use in science education. It was observed that the acquired data were classified under the subjects of effects on cognitive properties, use and affective properties. It was concluded that the studies help learning with a frequency of \% 12.0 , that they were effective learning tools with a frequency of \%8.0, that they increase the student performance with a frequency of $\% 8.0$ and increase the learning outcome with a frequency of \%8.0. In addition, it was also concluded that it makes lessons more fun due to its effects on affective properties with a frequency of $\% 8.0$ and that it increases the motivation/interest of students with a frequency of \%8.0.

5. What are the suggestions for researchers, teachers, curriculum developers and policy makers regarding the use of tablets in science education?

The data related with the suggestions included in studies carried out regarding tablet use in science education was showed in Table 16.

Table 16. Frequencies of studies by suggestions

\begin{tabular}{lll}
\hline Suggestions & $\mathrm{f}$ & $\%$ \\
\hline Code & 1 & 11.1 \\
\hline Preparation of software that leads and contains ready to use activities & 1 & 11.1 \\
Developing teaching methods that will enable sharing via tablets & 11.1 \\
Carrying out studies in which traditional methods are compared with tablet based & 1 & 11.1 \\
teaching methods & 1 & 11.1 \\
Carrying out more studies on higher level and education output & 1 & 11.1 \\
Carrying out studies to examine how tablets can be used more effectively & 1 & 11.1 \\
Increasing the number of studies that acquire data via various other methods & 1 & 11.1 \\
Modifying the applications used & 1 & 11.1 \\
Carrying out studies which examine the effects of applications developed & 1 & 1 \\
Carrying out studies with a greater number of participants & 9 & 100.0 \\
Total* & & 1
\end{tabular}

As can be seen from Table 16, it had been stated with a frequency of $\% 11.1$ that software that leads and contains ready to use activities should be developed, it had been stated with a frequency of \%11.1 that studies should be 
carried out in which traditional methods are compared with tablet based teaching methods and it had been stated with a frequency of \%11.1 that studies should be carried out that examine how tablets can be used more effectively.

\section{Discussion and Conclusions}

According to the results obtained from the study, it is observed that 25 studies carried out related with tablet use in science education. Only four of these studies published in Computers \& Education, Advances in Physiology Education and Journal of Chemical Education which were included in the SSCI/SCI scope. It was understood that the other studies generally published in international journals or presented at conferences. When journals and conferences were examined, it was observed that they were related with presenting and discussing new educational environments, best practices and case studies on innovative technology-based learning strategies, presenting activities, laboratory experiments, instructional methods and pedagogies. In addition, it was stated in journals and conferences that the objective was to develop the understanding of learning and teaching starting from pre-school to higher education and to contribute to the betterment of education. In this regard, it can be stated that the studies published in relevant journals or conferences. However, when the journals in which the studies published are examined, it is understood that in general they were the journals that focus more on education or science education. On the contrary, very few studies observed in technology focused journals related with tablet use in science education. In this regard, it was thought that more studies should be carried out related with tablet use in science education which aim to be published in technology focused and science education related publications. In addition, when the studies were examined it was observed that only four of the studies published in SSCI/SCI scope international journals. In this regard, it was understood that the number of studies on tablet use in science education was low in important journals surveyed via international databases. However, it was thought that this was more related with difficulties of publishment in SSCI/SCI scope international journals rather than being related with the topic itself. Olkun (2006) stated in a study that the two most important obstacles facing those who wish to publish in international scientific journals were their language proficiencies - their lack of being able to write in a scientific style and the fact that their research topics selected from among outdated or insignificant topics. When it was considered that tablet use in science education was a novel topic, it was thought that important publications can be carried out which can be published in important journals cited in indexes.

Studies related with tablet use in science education started to be carried out in 2007 that the number of studies increased to reach four in 2012 whereas nine studies were carried out in 2013. In this regard, it can be stated that parallel to the rapid advancements in technology, the number of studies had increased related with tablet use in science education. When we looked at 2014, it can be observed that there were six studies. This was thought that journals had not completed all their issues in 2014 and that conferences had not been carried out. In addition, it was observed as a result of the analyses made that 25 articles had been found. When a quantitative evaluation was made, it can be stated that the number of studies on tablet use in science education was very low. However, it was thought as a result of the studies carried out that the number of studies in this field had increased rapidly in 2013 and that they have continued to increase over time accordingly. In addition, even though studies on tablet use in science education examined, it was thought that some studies had not been reached. Because it was observed that in some studies the names of special applications used in tablets are used instead of the term tablet. In their study Looi, Chen and $\mathrm{Ng}$ (2010) used Group Scribbles in the science classroom and examined the learning effectiveness collaborative activities. They used Tablet PCs, but this word was not used title or keywords. Despite the use of tablets in some studies in the literature, the titles include general terms such as mobile devices or mobile learning environment. Liu, Lin and Paas (2014) examined the effects of prior knowledge on learning in a mobile learning environment about plant leaf morphology for primary school. Furió, González-Gancedo, Juan, Seguí and Costa (2013) presented an educational game for an iPhone and a Tablet PC about the water cycle. In this regard, there can be said that these and similar studies were related to the use of tablets in science education. In the review of study which the use of tablets in science education, we could not be reached to some studies. Because when it was looked at topics or keywords in the study, tablet or other mobile devices were being used which was not understood. When both the large number of applications used with tablets and the presence of many tools in mobile devices were considered, it was not possible to scan all applications and this was among the limitations of the study. In addition, it was known that the daily use of tablets and in parallel the use of tablets in educational environments started quite recently. Similarly, Ozkale and Koc (2014) asserted in their studies that there was a significant increase in the popularization of tablet computers starting with 2010 and beyond, but the number of studies examining the results of tablet computer use for educational purposes was almost rare. Accordingly, it was normal that the number of studies related with tablet use in science education was low. 
As a result of the analyses carried out, it was observed that the authors made publications generally as one, two or three authors. Bacanak, Degirmenci, Karamustafaoglu and Karamustafaoglu (2011) carried out a study in which they examined the articles on science education regarding the number of authors in which they concluded that $2 / 3$ of the studies have one or two authors. In this regard, it can be concluded that the studies were generally carried out with a smaller number of authors. It was observed as a result of the analysis carried out that the highest number of studies on tablet use in science education were carried out in Turkey and United States followed respectively by Canada, United Kingdom and Japan. It can be stated that this was because of technology supported applications started to be incorporated in the education policies of the countries which in parallel had led to the increased use of tablet use in classrooms. Many projects was carried out in recent years in the world and in Turkey which were related with the integration of technology to education and many projects was applied in the USA to spread the use of technology at the national and state level (Pamuk, Cakir, Ergun, Yilmaz and Ayas, 2013). Reynolds (2011) carried out a study in US in which he stated that in parallel with the popularity of tablets and smart phones, they carried out a study putting forth that they reach \%20 of the university students until the end of 2012. Whereas in Turkey, the FATIH Project anticipates the provision of laptops, LCD panel, interactive board and internet infrastructure to ensure that information technologies appeal to a greater number of senses in the learning-teaching process in order to enhance technology used at schools and to ensure the equality of opportunity in education (FATIH 2013). In this regard, it was observed that schools and educational environments have been carried out projects related with the use of technology and tablets. It can be stated in parallel that the number of studies was greater on tablet use in these countries. However, it can also be stated that the number of studies was limited and that there was a need for more studies.

The rationales for studies on tablet use in science education specified as, the fact that the number of tablet related studies was low (Balci, Kenar and Usak, 2013), insufficiency of tablet related materials for teachers (Egusa et al., 2014), popularization of tablet use in education (Daikoku, Funaoi, Kusunoki, Takenaka and Inagaki, 2013) and the increase of student learning as a result of tablet use (Director and Hrepic, 2007). It can be seen in the stated rationales that in general the insufficiency in the field was emphasized. Ozkale and Koc (2014) underlined that scientific studies that examine the use of tablets in educational environments in Turkey as well as their educational potential had increased with the FATIH project but also added that the number of studies was still limited. In this regard, it was quite normal to state the insufficient number of studies on tablet use in science education as a rationale for conducting studies in this field. Whereas six of the rationales put forth in the studies were related with science, rationales regarding tablet use in education had been put forth without establishing a relation with science in 10 studies. When it was considered that all the studies carried out are related with tablet use in science education, the rationales should be related not only with tablet use in education but also with the nature of science as well. In addition, some studies did not include these at all which can be specified as a shortcoming of these studies with regard to their value. In this regard, it was thought that when writing down the studies related with tablet use in science education, stating the rationales and relating tablet use with science will increase the quality of the studies carried out.

It was determined as a result of the studies carried out that the objectives of the studies carried out on tablet use in science education were examination of the effects of tablets on the student (Morris, Ramsay and Chauhan, 2012), on student performance (Pryor and Bauer, 2008) and the examination of the effectiveness of tablet material (Daikoku et al., 2013). In addition, there were also studies in the relevant literature in which opinions of teachers related with tablets were taken (Dasdemir, Cengiz, Uzoglu and Bozdogan, 2013), which aim to develop tablet applications (Erhart, 2013) and which examine the attitudes of students regarding technology in tablet applications (Kenar, Balci and Gokalp, 2013). When the objectives of the studies were examined, it can be observed that studies generally carried out to examine the effects of tablets on student performance, success, attitude, learning gains or outputs. In this regard, it can be stated that the studies focused only on cognitive properties and attitude. Even though there were many variables which studies by can be establishing a relation between science and technology (tablets, smartboards etc.), no studies were determined which examine the effects of tablet use on different variables such as entrepreneurship, knowledge and communication skills. In addition, it can be stated as a result of the analyses carried out that there were studies which aim to develop tablet applications. It was considered that these studies were important for the field and that the tablet applications which will be developed by establishing a relation between science education and tablets will be important for school managers, teachers, teacher candidates and students. It can be stated that such studies will be important for the field.

It was observed that experimental/empirical method (Nedungadi, Raman and McGregor, 2013; Pryor and Bauer, 2008; Schneps, Ruel, Sonnert, Dussault, Griffin and Sadler, 2014), descriptive survey (Dasdemir et al., 2013), case study (Egusa et al., 2014; Price and De Leonce, 2008) and survey method (Kucukaydin, Bozdogan and 
Ozturk, 2014) was used in studies on tablet use in science education. In addition, it was also understood that experimental/empirical method, mixed method and controlled study was used in SSCI/SCI scope journals, whereas experimental method, descriptive survey, survey method was used in international journals. It can be expressed as a result of the analyses that the number of qualitative studies was very low and these are the studies in which general opinions required regarding tablets. In addition, it was observed in many studies that the effectiveness of tablet use examined on different variables such as attitude, learning, concept and perception. In this regard, it was thought that long-term qualitative studies should also be carried out in addition to studies using experimental design which examine the effectiveness with regard to certain variables.

When the study group and sample groups in studies on tablet use in science education were examined, it was observed that 0-30, 31-100 and 101-200 people had been used in SSCI scope journals. Whereas the number of participants for articles published in international journals varies between 101-200, 31-100 or 201 and above. In this regard, it was normal to work with a greater number of participants if it is considered that the studies were more quantitative. When the sample group types was examined, it was observed that teacher candidates was preferred in studies published in SSCI scope journals, whereas students and teacher candidates was preferred for studies published in international journals and students were used for conferences. In general, it can be said that studies carried out with students and teacher candidates. This was since the studies to examine the effects of tablet applications in science education on the students or the examination of student related issues. In addition, it can be stated that there is need for a greater number of studies with a wider scope which will be carried out with students and teachers.

It was observed as a result of the analyses carried out that the data acquisition tools used in the studies were likert type scale (Olsson, 2013), questionnaire (Green, Hechter, Tysinger and Chassereau, 2014; Revell, 2013; Slough, Erdogan, Cavlazoglu, Wakefield and Akgun, 2012), open ended question (Kucukaydin et al., 2014) and multiple choice test (Pryor and Bauer, 2008). Likert type scale, questionnaire, observation, multiple-choice test, rubric, online homework or standard exam was used in studies carried out within the scope of SSCI. Whereas it was observed that likert type scale, open ended question or closed ended question was used as data acquisition tools in international studies. As stated by Simsek et al. (2009), it can be stated that the reason for the preference of surveys, tests and scales was the fact that survey studies carried out more within the scope of quantitative paradigms. In this regard, likert type scale, multiple choice test and questionnaire was used even though the studies were mainly quantitative. On the other hand, it was understood that the number of studies was quite low in which various methods such as observation and interview were used which were mainly used in qualitative studies.

It was determined as a result of the analyses carried out that in some of the studies examined standard tablet applications that come with the tablets was used, whereas in others tablet applications developed by the researchers was preferred and studies was carried out accordingly. Windows Journal (Antimirova and MilnerBolotin, 2010; van Oostveen, Muirhead and Goodman, 2011) and Dy Know Visionsoftware (Director and Hrepic, 2007; Hrepic and Miller, 2009) applications was preferred in tablet applications used studies. In addition, it was also observed that applications were used such as Classroompresenter, InkSurvey, Case method teaching material manga, TheApp CLAST (Macario, Cattadori, Bianchi, Zattin and Talarico, 2013), Educreations (Lehtinen and Viiri, 2014).. In this regard, it can be stated that it would be suitable to developed applications which can be used in science education or to carry out studies by establishing the relationships between existing applications and science. It was determined as a result of the study carried out that tablets used most extensively for the electricity subject as well as in chemistry concepts/course, physics concepts/course, physics lessons and biology lessons/laboratory. In addition, it was also observed that there are studies on the use of tablets in laboratory classes as well. This was thought that simulations and animations were used more extensively for such topics or during laboratory courses. In addition, when the analyzed studies were examined, it was observed that research studies carried out in physics, chemistry and biology lessons but that these were not subject based studies. In this regard, when it was considered that there were tablet applications suited for each topic; it was very likely for studies to be carried out on all topics.

When the main results acquired from the study on tablet use in science education were examined, it was concluded that tablets help learning with regard to cognitive features (Kucukaydin et al., 2014), that it was an effective learning tool (Egusa et al., 2014), that it increases student performance (Leenaars et al., 2012) and that it increases learning outputs (Hrepic and Miller, 2009). As can be understood, the use of tablets in science education made positive contributions to the learning of students. In addition, it was also concluded that tablets make the lessons more fun due to their effects on cognitive properties (Uzoglu and Bozdogan, 2012) thus increasing the motivation/interest of students (Dasdemir et al., 2013). It can be put forth that the interest of technology age individuals increase with tablet use and that a more entertaining classroom environment was 
attained. It was suggested as a result of the analyses made with regard to tablet use that guiding software's should be developed which contain ready activities (Ozdemir and Bozdogan, 2014), that studies should be carried out which compare traditional methods of teaching with tablet based teaching (Erhart, 2013) and that methods for increasing the effectiveness of tablets should be examined (Leenaars et al., 2012).

\section{Recommendations}

When studies on the use of tablets in science education were examined, it was observed that the use of computers, smartboards and tablet applications increase along with technological advancements and that studies related with these topics were being carried out. However, it can be stated that the number of such studies was limited and that there were many gaps in the field which should be filled with further studies. It was understood that the studies carried out with regard to tablet use in science education were mostly experimental and that they focus more on cognitive properties and the attitude towards technology. On the contrary, there was a need for studies that examine the effects of tablets on the creativity, entrepreneurship, knowledge and communication skills of students by establishing the relation between science education and tablets. In addition, studies should be carried out which use many data acquisition tools together such as interview, observation and surveys to relate the data acquired as such in order to be able to publish the studies in SSCI scope journals. It can thus be stated that such studies were required for tablet use as well.

It can be stated that there were studies which aim to develop tablet applications among the examined studies. It was thought that these studies were important for teachers, students as well as the researchers in the field. Because the applications that will be developed can be tested by the researchers and applied by the teachers and students thus ensuring the use of different materials during the lessons. In this regard, it was thought that tablet applications that will be developed by relating them with science will be important for the relevant literature and that they will fill wide gaps in the field. It can be suggested to develop tablet applications by establishing relations between science and tablet use and to carry out studies which test these applications.

It was observed that tablet applications were made and their effectiveness was examined in the studies. However, no study was found which examine the effects of tablet use with regard to safety and health. In this regard, it was thought that studies should be carried out which examine the effects of tablet use in classrooms on the health and safety of individuals. In addition, it was thought that it will be important to carry out studies focusing on the provision of individual and tablet interaction.

\section{References}

Amirnudin, M. T. M. \& Sulaiman, H. (2013). Exploring the Use of Tablet Technology as a Teaching Tool at Kolej Matrikulasi Perak. The 20 $0^{\text {th }}$ National Symposium on Mathematical Sciences: Research in Mathematical Sciences: A Catalyst for Creativity and Innovation, April, 590-595, Putrajaya, Malaysia.

Antimirova, T. \& Milner-Bolotin, M. (2010). HP Grants for Tablet Technologies in Science Teaching: From Dream to Innovation. INTED Proceedings, March, 3432-3443, Valencia, Spain.

Avraamidou, L. (2008). Prospects for the Use of Mobile Technologies in Science Education. AACE Journal, 16 (3), 347-365.

Bacanak, A., Degirmenci, S., Karamustafaoglu, S. \& Karamustafaoglu, O. (2011). Published science education articles in e-journals: Method analysis. Journal of Turkish Science Education, 8(1), 119-132.

Balci, M., Kenar, I. \& Usak, M. (2013). The attitudes of students' parents towards tablet pc supported science and technology course. Turkish Studies - International Periodical for the Languages, Literature and History of Turkish or Turkic, 8 (8), 1687-1702.

Calik, M., Ayas, A. \& Ebenezer, J. V. (2005). A review of solution chemistry studies: insights into students' conceptions. Journal of Science Education and Technology, 14 (1), 29-50.

Cao, H. (2014). A tablet based learning environment. arXiv preprint arXiv: 1403.6006.

Chambers, Z., Chidanandan, A., DeVasher, R., Merkle, L., Minster, M., Mitra-Kirtley, S., ... \& Zoetewey, M. (2006). What is Beyond the Laptop Initiative? Perhaps: Tablet Pcs and Dyknow Vision Software. Frontiers in Education Conference, October, 36th Annual, 8-13, San Diego, California.

Cepni, S. (2014). Introduction to research and project work (7. Printing). Celepler Printing, Trabzon

Chen, F. \& Sager, J. (2011). Effects of tablet pc use in the classroom on teaching and learning processes. Learning in Higher Education, 7 (2), 55-67.

Cicchino, R. \& Mirliss, D. (2004). Tablet Pcs: A Powerful Teaching Tool. World Conference on E-Learning in Corporate, Government, Healthcare, and Higher Education, 543-548. 
Cuhadar, C. (2014). Information technologies pre-service teachers' acceptance of tablet pcs as an innovative learning tool. Educational Sciences: Theory \& Practice, 14(2), 741-753.

Daikoku, T., Funaoi, H., Kusunoki, F., Takenaka, M. \& Inagaki, S. (2013). Development and Evaluation of Case Method Teaching Materials Using Manga on Tablet Pcs: A Scene Awareness Entry-Type Trial. $5^{\text {th }}$ International Conference on computer Supported Education, May, 557-563, Aachen, Germany.

Dasdemir, I., Cengiz, E., Uzoglu, M. \& Bozdogan, A. E. (2013). Examination of science teachers' opinions related to tablet pcs using in science and technology courses. Mustafa Kemal University Journal of Social Sciences Institute, 9 (20), 495-511.

Director, H. \& Hrepic, Z. (2007). Using Tablet Pcs to Explore Interactive Learning Environment: Engage Students in Learning. World Conference on Educational Multimedia, Hypermedia and Telecommunications, June, 579-586, Vancouver, BC Canada.

Egusa, R., Funaoi, H., Daikoku, T., Inai, R., Kusunoki, F., Takenaka, M., Terano, T. \& Inagaki, S. (2014). Improving the Usability of Manga-on-a-Tablet for Collaborative Learning. $6^{\text {th }}$ International Conference on Computer Supported Education, April, 446-451, Barcelona, Spain.

El-Gayar, O. F., Moran, M. \& Hawkes, M. (2011). Students' acceptance of tablet pcs and implications for educational institutions." Educational Technology \& Society, 14 (2), 58-70.

Enriquez, A. (2009). Using Tablet Pcs to Enhance Student Performance in an Introductory Circuits Course. 2009 American Society of Engineering Education/Pacific Southwest Section Conference, San Diego, CA, 19-20.

Enriquez, A. G. (2010). Enhancing student performance using tablet computers. College Teaching, 58 (3), 77 84.

Erhart, S. E. (2013). The creation and utilization of a physical science tablet application in the primary classroom a thesis submitted to the graduate school. Doctoral dissertation, Ball State University, Indiana.

FATIH 2013. http://fatihprojesi.meb.gov.tr/tr/icerikincele.php?id=6 (Retrieved from the website on January 24 , 2013).

Furió, D., González-Gancedo, S., Juan, M. C., Seguí, I. \& Costa, M. (2013). The effects of the size and weight of a mobile device on an educational game. Computers \& Education, 64, 24-41.

Galligan, L., Loch, B., McDonald, C. \& Taylor, J. A. (2010). The use of tablet and related technologies in mathematics teaching. Australian Senior Mathematics Journal, 24 (1), 38-51.

Gill, T. G. (2007). Using the tablet pc for instruction. Decision Sciences Journal of Innovative Education, 5 (1), 183-190.

Gorgievski, N., Stroud, R., Truxaw, M. \& DeFranco, T. (2005). Tablet pc: A preliminary report on a tool for teaching calculus. International Journal for Technology in Mathematics Education, 12 (3), 95.

Green, L. S., Hechter, R. P., Tysinger, P. D. \& Chassereau, K. D. (2014). Mobile app selection for 5th through 12th grade science: The development of the MASS rubric. Computers \& Education, 75, 65-71.

Gubacs-Collins, K. \& Juniu, S. (2009). The mobile gymnasium: using tablet pcs in physical education. Journal of Physical Education, Recreation \& Dance, 80 (2), 24-31.

Hocanın, F. T. \& Iscioglu, E. (2014). Use of mobile tablets in the learning environment: Perspective of the computer teacher candidates. Journal of Educational \& Instructional Studies in the World, 4 (2), 13-17.

Hrepic, Z. \& Miller, K. (2009). Impact of tablet pcs and DyKnow software on learning gains in inquiry-learning oriented course. The impact of tablet PCs and pen-based technology on education: New horizons, 65-72.

Ilyasoglu, U. \& Aydin, A. (2014). The effect of computer assisted teaching on the science and technology teacher candidates' achievement in the direct current circuits teaching. Kastamonu Education Journal, 22 (1), 223-240.

Inagaki, T., Nakagawa, H., Murai, M., Shimizu, M., Nakahashi, Y., Uchigaito, T., ... \& Futaki, S. (2011). What do Interactive Whiteboards and Tablet PCs Bring to a Classroom? World Conference on Educational Multimedia, Hypermedia and Telecommunications, June, 406-411, Lisbon, Portugal.

Kenar, I., Balci, M. \& Gokalp, M. S. (2013). The effects of tablet computer assisted instruction on students' attitude toward science and technology course. Kamla-Raj: International Journal of Educational Sciences, 5 (3), 163-171.

Kucukaydin, Z., Bozdogan, A. E. \& Ozturk, P. (2014). Secondary school students' views in a village school about the use of tablet computers in science course. Mevlana International Journal of Education (MIJE), 4 (2), 53-59.

Kurnaz, M. A., \& Calik, M. (2009). A thematic review of 'energy' teaching studies: Focuses, needs, methods, general knowledge claims and implications. Energy Education Science and Technology Part B: Social and Educational Studies, 1 (1), 1-26.

Leenaars, F., van Joolingen, W., Gijlers, H. \& Bollen, L. (2012). Drawing-Based Simulation for Primary School Science Education: An Experimental Study of the Gearsketch Learning Environment. IEEE Fourth International Conference on Digital Game and Intelligent Toy Enhanced Learning, March 1-8, Takamatsu, Japan. 
Lehtinen, A. \& Viiri, J. (2014). Using tablets as tools for learner-generated drawings in the context of teaching the kinetic theory of gases. Physics Education, 49 (3), 344.

Li, K. \& Akahori, K. (2007). The effects of handwritten feedback on paper and tablet pc in learning japanese writing. International Journal of Emerging Technologies in Learning (IJET), 2 (4), 54-60.

Lim, K. Y. (2011). What does the tablet pc mean to you? A phenomenological research. Innovations in Education and Teaching International, 48 (3), 323-333.

Liu, T. C., Lin, Y. C. \& Paas, F. (2014). Effects of prior knowledge on learning from different compositions of representations in a mobile learning environment. Computers \& Education, 72, 328-338.

Looi, C. K., Chen, W. \& Ng, F. K. (2010). Collaborative activities enabled by GroupScribbles (GS): An exploratory study of learning effectiveness. Computers \& Education, 54 (1), 14-26.

Macario, M., Cattadori, M., Bianchi, C., Zattin, M. \& Talarico, F. (2013). CLAST: A Science Education App for Tablet Examining the Dynamic of an Antarctic Glacial System. International Conference New Perspective in Science Education, March, Florence, Italy.

Moore, E., Utschig, T. T., Haas, K. A., Klein, B., Yoder, P. D., Zhang, Y., \& Hayes, M. H. (2008). Tablet pc technology for the enhancement of synchronous distributed education. Learning Technologies, IEEE Transactions on, 1 (2), 105-116.

Morris, N. P., Ramsay, L., \& Chauhan, V. (2012). Can a tablet device alter undergraduate science students' study behavior and use of technology? Advances in Physiology Education, 36 (2), 97-107.

Nedungadi, P., Raman, R., \& McGregor, M. (2013). Enhanced STEM Learning with Online Labs: Empirical Study Comparing Physical Labs, Tablets and Desktops. Frontiers in Education Conference, IEEE, October, 1585-1590, Madrid, Spain.

Nye, S. B. (2010). Tablet PCs: A physical educator's new clipboard. Strategies, 23 (4), 21-23.

Olkun, S. (2006). Editorial Processes of Academic Journals Related to Education: Problems, Solutions and opportunities. Periodical Publishing in Social Sciences - First National Conference Proceedings, Ankara.

Olsson, A. (2013). SimPad-a drawing-based modeling tablet web application to support science education." Unpublished Master Thesis, Malmö University, Sweden.

Ormanci, U., Cepni, S., Deveci, I. \& Aydin, O. (2015). A thematic review of interactive whiteboard use in science education: rationales, purposes, methods and general knowledge. Journal of Science Education and Technology, 24 (5), 532-548.

Ozdemir, U. \& Bozdogan, A. E. (2014). Examination of views on the use of science teachers in the course of the tablet pc in terms of different variables: A sample of Giresun. Cumhuriyet International Journal of Education, 3 (1), 59-73.

Ozkale, A. \& Koc, M. (2014). Tablet computers and their usage in educational settings: A literature review." SDU International Journal of Educational Studies, 1 (1), 24-35.

Ozok, A. A., Benson, D., Chakraborty, J. \& Norcio, A. F. (2008). A comparative study between tablet and laptop PCs: User satisfaction and Preferences. Intl. Journal of human-computer interaction, 24 (3), 329352.

Pamuk, S., Cakir, R., Ergun, M., Yilmaz, H. B. \& Ayas, C. (2013). The use of tablet pc and interactive board from the perspectives of teachers and students: Evaluation of the FATIH project. Educational Sciences: Theory \& Practice, 13 (3), 1799-1822.

Park, E., \& del Pobil, A. P. (2013). Technology acceptance model for the use of tablet PCs." Wireless Personal Communications, 73 (4), 1561-1572.

Price, E. \& De Leone, C. (2008). Archiving Student Solutions with Tablet PCs in a Discussion-Based Introductory Physics class. AIP Conference Proceedings, October, 1064 (1), 175.

Pryor, G. \& Bauer, V. (2008). Building a better biology lab? Testing tablet Pc technology in a core laboratory course. Journal of College Science Teaching, 38 (2), 44-48.

Reboli, D. (2007). Introducing a Tablet PC into any Classroom: Bringing Ideas from a High School into a College Classroom. Society for Information Technology \& Teacher Education International Conference, March, 3319-3324.

Reynolds, R. (2011). Trends influencing the growth of digital textbooks in US higher education. Publishing Research Quarterly, 27 (2), 178-187.

Revell, K. D. (2013). A comparison of the usage of tablet PC, lecture capture, and online homework in an introductory chemistry course." Journal of Chemical Education, 91 (1), 48-51.

Romney, C. A. (2011). Tablet PC Use in Freshman Mathematics Classes Promotes STEM Retention. Frontiers in Education Conference (FIE), October, USA.

Roschelle, J., Tatar, D., Chaudhury, S. R., Dimitriadis, Y., Patton, C. \& DiGiano, C. (2007). Ink, Improvisation, and Interactive Engagement: Learning with Tablets. IEEE Computer, 40 (9), 42-48.

Schnackenberg, H. L. (2013). Tablet technologies and education. International Journal of Education and Practice, 1 (4), 44-50. 
Schneps, M. H., Ruel, J., Sonnert, G., Dussault, M., Griffin, M. \& Sadler, P. M. (2014). Conceptualizing astronomical scale: Virtual simulations on handheld tablet computers reverse misconceptions. Computers \& Education, 70, 269-280.

Sheehy, K., Kukulska-Hulme, A., Twining, P., Evans, D., Cook, D. \& Jelfs, A. (2005). Tablet PCs in schools: A review of literature and selected projects.

Simsek, A., Ozdamar, N., Uysal, O., Kobak, K., Berk, C., Kilicer, T., \& Cigdem, H. (2009). Current trends in educational technology research in turkey in the new millennium. Educational Sciences: Theory \& Practice, 9 (2), 115-120.

Slough, S., Erdogan, N., Cavlazoglu, B., Wakefield, J. \& Akgun, O. (2012). Designers Discussing Design: An Investigation into the Design of an Innovative Science Textbook Designed to Take Advantage of MultiTouch Tablet Technology and the Cloud. World Conference on Educational Multimedia, Hypermedia and Telecommunications, June, 1, 1227-1232, Denver, Colorado.

Straker, L. M., Coleman, J., Skoss, R., Maslen, B. A., Burgess-Limerick, R. \& Pollock, C. M. (2008). A comparison of posture and muscle activity during tablet computer, desktop computer and paper use by young children. Ergonomics, 51 (4), 540-555.

Tekbiyik, A. \& Akdeniz, A. R. (2010). A meta-analytical investigation of the influence of computer assisted instruction on achievement in science. Asia-Pacific Forum on Science Learning and Teaching, 11 (2), 122.

Tran, D., Ma, W., Sharma, D. \& Liu, S. (2006). Tablet PC Applications in an Academic Environment. The First International Conference on Theories and Applications of Computer Science, August, Vietnam, 121-134.

Ultay, N. \& Calik, M. (2012). A thematic review of studies into the effectiveness of context-based chemistry curricula. Journal of Science Education and Technology, 21(6), 686-701.

Uzoglu, M. \& Bozdogan, A. E. (2012). An examination of preservice science teachers' views related to use of tablet pcs in science and technology course in terms of different variables. Mevlana International Journal of Education (MIJE), 2 (1), 1-14.

van Oostveen, R., Muirhead, W. \& Goodman, W. M. (2011). Tablet PCs and reconceptualizing learning with technology: a case study in higher education. Interactive Technology and Smart Education, 8 (2), 78-93.

Varank, I., Yeni, S. \& Gecu, Z. (2014). Student's opinions for using tablet pcs in education: A case study. Journal of Theoretical Educational Science, 7 (2), 135-147.

Willis, C. L. \& Miertschin, L. (2004). Tablet PC's as Instructional Tools or the pen is Mightier than the'board!." 5th Conference on Information Technology Education, October, 153-159, Istanbul, Turkey.

\begin{tabular}{lc}
\hline & Author Information \\
\hline Ummuhan Ormanci & Salih Cepni \\
Uludag University & Uludag University \\
Science Education, Bursa, Turkey & Science Education, Bursa, Turkey \\
Contact e-mail: ummuhan45@gmail.com & \\
\hline
\end{tabular}

